\title{
A Cognitive Analysis of Advance Student-Teachers' Reading Performance in an ESL Context
}

\author{
OLAJIDE, Stephen Billy, Ph.D. \\ English Education Unit, Department of Arts and Social Sciences Education, University of \\ Ilorin, Ilorin, Nigeria \\ E-mail: billyolajide@ unilorin.edu.ng
}

Accepted: November 24, 2012 Published: December 23, 2012

Doi:10.5296/ijld.v2i6.2952ＵRL: http://dx.doi.org/10.5296/ijld.v2i6.2952

\begin{abstract}
Reading, a literacy skill with fundamental contribution to intellectual development, is cognitively ignited, propelled and actualized. For nearly a century, scholars have concerned themselves with exploring the cognitive basis of reading in order to improve comprehension performance. In Nigeria where English is a Second Language (ESL), worries have been expressed that student-teachers in Colleges of Education, like other categories of learners, are poor readers. The problem has been attributed partly to poor cognitive skills, and it has implication for teacher preparation: it may have adverse effects on the future of secondary school learners who are supposed to be taught by the student-teachers after the latter might have graduated from the colleges. In this paper, an attempt is at identifying, quantifying and evaluating the cognitive components of the comprehension performance of the advance student-teachers with a view to showing how such components may be enhanced in teacher preparation program for greater national development and progress.
\end{abstract}

Key words: Cognitive Skill, Student-Teacher, Reading Performance, Specialization, Text structure

\section{Theoretical Background}

Thorndike's (1917) exposition that reading embeds reasoning was a significant attempt at sensitizing reading scholarship to the cognitive trappings of reading. Since then, debates have been raging on the actual nature and intents of reading as a language art. For example, Whorf (1941) deposed that language shapes the human thought and learning ability, although Lenneberg (1953) viewed the Whorfian hypotheses as a weak way of explaining the link between man's intellectual performance and his thought.

One may not be able to rely on ordinary linguistic facts to illuminate written information most meaningfully, especially if such information is larger than morphemes. It is in this connection that Lenneberg (1953) proposed a model for explaining how language relates to the human mind. His model: identifying the process of encoding, examining the code itself, and scrutinizing the process of the coding. The strength of Lenneberg's assumption also seems to be its relevance to the quest to widen the communicative scope of reading through a cognitive window. 
Also, Piagent (1954) advanced a theory to explain the cognitive content of language. He observed that human language develops in stages, and that each stage is characterized by language behavior. He, thus, objected to the assumption by Whorf (1941) and Lenneberg (1953) that language and thoughts are inter-independent, and that the former determines the latter. Piaget suggested that language is symbolic; each symbol being simpler than the collective sign. According to him, thinking precedes language, the latter confining itself to transforming the former through an equilibrium that involves schematization and abstraction. This view has been shared by May (1986) who maintained that reading performance could be improved by enhancing the readers "background schemata" (p. 77).

In a rather different dimension, Chomsky (1968) viewed language as being acquired by an innate device; he did not subscribe to the theory that man learns language in compartmentalized stages, as "it is difficult to see what link these stages share at all" (p.326). Yet he is agreed with Lenneberg (1953) who observed that language is purposive because the user intends to communicate with it. Chomsky strongly opposed the atomistic idea that language emerges from simpler system, and maintained that making meaning from any utterance requires a special type of mental organization. Language, to him, is syntactic stringing smatter utterances together to form the sentence; it is a performance based on a structured and coherent internal organization. Thus, he recommended that how man makes meaning from an utterance (written or spoken) should be thoroughly investigated so that the distinctive properties of human intelligence may be ascertained and enhanced creatively.

How children derived meaning from the printed word interested Smith, Goodman and Meredith (1976) and May (1986): they found that the child's ability to derive the meaning is a cognitive feat, and they equated meaning to self awareness. They canvassed that reading comprehension is a cognitive activity that has considerably implication for intellectual and socio-emotional development.

Following Smith et al. (1976), Unoh (1991) asserted that reading has a great impact on intellectual development. He identified the characteristics of efficient reading to include:

... general intelligence, visual and auditory perception and

discrimination, physical maturity and health, freedom from directional confusion, adequate background experience, comprehension and use of oral language, emotional and interest in books and in reading (p.5).

According to him, negative attitude to reading instruction and reading tasks could impair intellectual development.

In the same vein, Guilford (1970) noted that human intellect involves cognitive recognition and structuring of information, memory (reaction and information), and divergent production (conclusion and inductive thinking). He averred that every phase of human intellect is characterized by particular linguistic skills, ranging from the word, sentence, ideational analysis and synthesis to application. Guilford held that text structure could considerably influence how the text is comprehended.

Spache and Spache (1973) considered Guilford's (1970) model as a strong explanation of the reading process. Consequently, they suggested that word-meaning relationships, the relationship among the writer's ideas, and appraising the cognitive demands of the text being confronted should be emphasized in a program of reading. Towards strengthening the Guilford postulation, Glassman (2002) proposed a thematic curriculum where reading can be taught effectively by the use of "brainstorming" and "think storming" (p.2). Also, Adeyemi (2011), 
Olajide $\left(2011^{\mathrm{a}}\right)$ and Olawuyi, Durosaro, Olasehinde and Yahaya (2011) advocated the vigorous teaching of thinking to advanced students.

Although, there has been no general agreement on the role of gender in the performance of human tasks, the world has been engaged in scholarly debates on the issue for quite some time. For example, Cronin (2005) alluded to the Darwinian theory of Evolution to affirm that man and woman are not the same. According to her, they cannot perform equally in nearly all human endeavors. On the other hand, Lewellyn-Jones (2009), Eckert and McConnell-Ginnett (2003) and Eccles, Wilgfield, Harold and Bloomfield (1993) opined that given the same opportunity, man and woman can perform at the level. They argue that woman's muscular deficit does not constitute a disadvantage for her in the performance of physical and mental tasks. Which is why, today, women sprint and play football as efficiently as men. The latter view is in line with Abe (1991) who maintained that gender does not determine how well a language teacher performs in the classroom.

Olajide (1997) reported that subject specialization could affect performance on reading tasks. The closer a text to one's specialization, the likelier it is that one would perform well on the text. (The converse may also be true).

James (1985) investigated into the cognitive demands by jamb questions. The studies, consistent with PIaget (1954), Rumelhart (1981) and Spache and Spache (1973), was based on the assumption that everybody has a pool of stored information about the world. The information is packed in elastic and schematic unit which processses and integrates new information for the process of facilitating comprehension and generating additional schemata. James (1985) insisted that the reader must make cognitive contribution to any text being read. In that connection, she proposed three types of cognitive skills, recall of facts, details, trends and sequences; interpretation and analysis, application and syntheses, and knowledge of vocabulary and terminology-that examination questions should target. She found that the Joint Admissions and Matriculation Board (JAMB) examiners used a variety of questions, demanding considerable power of terminology from the candidates. The examiner questions were also suited to the cognitive responses expected of the candidates. However, James observed that little emphasis was laid on higher cognitive skills by the questions posed. Although, she admitted that essay type questions could effectively elicit higher order cognitive skills, she reiterated that objective type questions have greater contents and predictive validity. According to her, tertiary students, especially those at the university should be engaged in reading activities which would enhance the development of higher order cognitive skills.

Also, Lawal (1993) studied the relationship between students reading performance in English at the secondary school level. He observed the classroom practice of the teachers and evaluated the use they made of the questions contained in prescribed basal materials. His findings: the teachers' questions did not sufficiently task the learners cognitively. Most of the teachers did not seem to appreciate the need to prepare the learners' minds for reading comprehension activities.

In a study of the cognitive content of teachers question in the language and communication skills courses of the Nigerian Colleges of Education, Olajide (1999) corroborated Lawal (1996). Most of the questions targeted the lower order skills of thinking rather than the higher order ones as expected at that level of learning. According to him, the teachers may have lacked the skills needed for evaluating the essential higher order cognitive skills.

In order to identify and explain the causes of poor reading skills among University students in Nigeria, Olajide (1991) also studied the reading comprehension performance of students at the University of Ilorin. His instrument comprised a test and a structured questionnaire which elicited responses from the subjects on the recognition, literal, inferential, critical and creative 
skills of reading. He found that subject specialization was a predictor of performance in reading. Also, it was observed that the student did not possess the higher order skills of comprehension. Students that were favorably disposed to reading as a subject were found to have performed well. Olajide inferred from that study that the university students were not efficient readers, and that there was a relationship between student's attitude and performance in reading to learn in English at that level.

Therefore, from the available literature, it can be deduced that whether reading will be successful depends on the reader's comprehension skills. Moreover, it is evident that language and cognition are intertwined in terms of skills and sub-skills which are schematic, elastic and hierarchical. One cognitive activity entails a corresponding linguistic activity and both activities lead to effective reading comprehension. For the present study, all psycholinguistic and reading comprehension activities are regarded as being propelled by intelligence and other innate attributes of the reader. As such, the study was based on a cognitive assumption which dimensions include:

a. Recognition that entails the linguistic skill of identification which ensures literal comprehension;

b. Deduction, involving interpretation and the drawing of inferences;

c. Analysis that requires evaluation and critical perception

d. Synthesis, which comprises construction and creativity.

Recognition and deduction were regarded as lower order while analysis and synthesis constituted the higher order cognitive skills. The model proposed below by this author probably helps to bring the assumption of the study to sharper focus. 


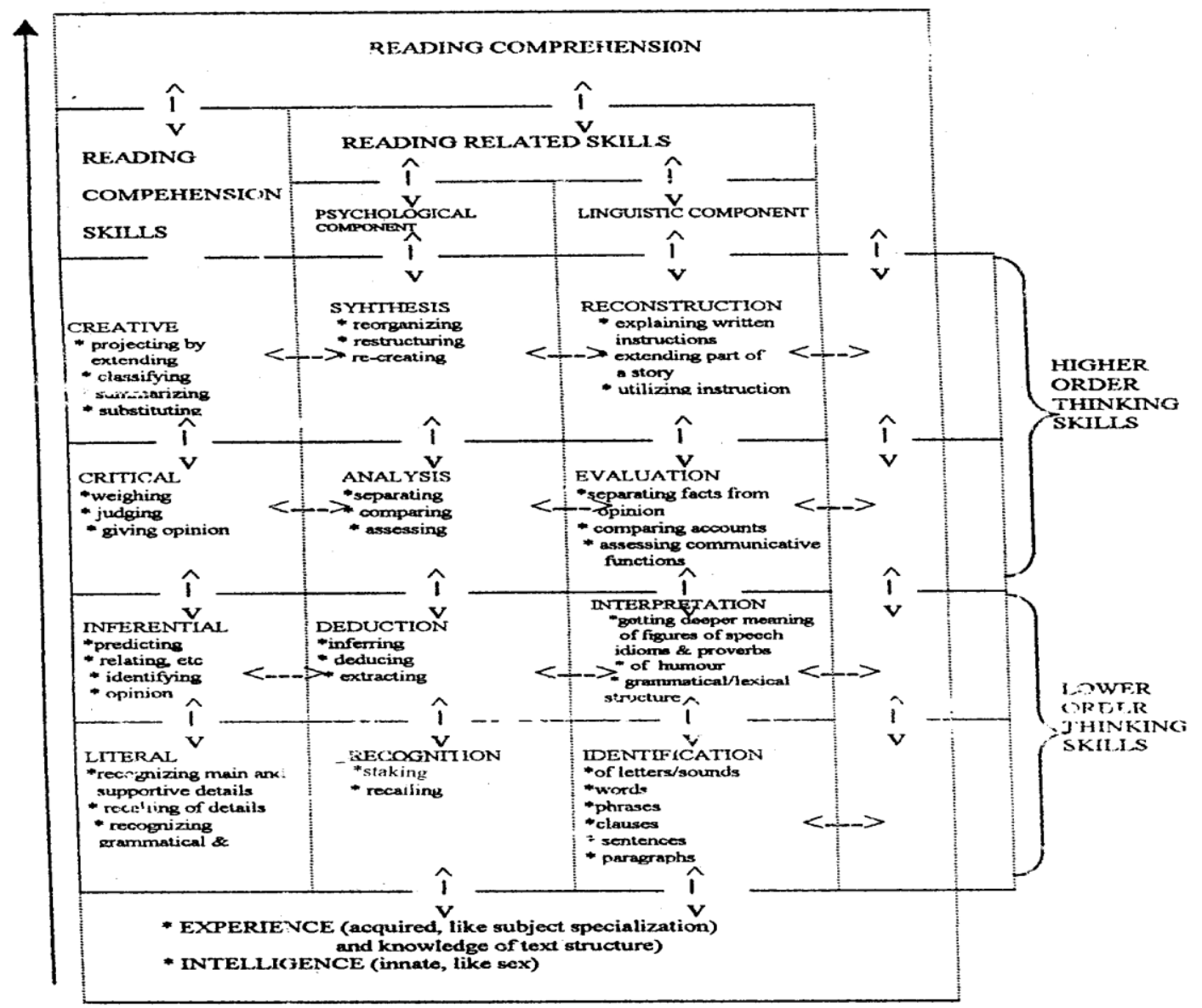

FGURE 1: A psycholinguistic model of reading 
The model presents reading comprehension skills as being intricate, related to the psychological and linguistic sub-skills. Each reading comprehension skill entails corresponding psycholinguistic activities, which can be promoted and evaluated through reading comprehension performance. Again, all reading comprehension and psycholinguistic skills and sub-skills are presumably rooted in the reader's personal experience and innate attributes. For the purpose of the present study, subject specialization and structure of the text relate to personal experience while gender is the innate attribute. The arrow on the left hand side of the model indicates the upward progressive development of reading comprehension and psycholinguistic skills starting from the genetic base that enshrines intelligence and experience.

\section{Problem and Purpose of the Present Study}

While effective cognitive processes determine reading efficiency, which in turn affects learner achievement in language and the development of critical and creative abilities, how cognition affects reading comprehension performance in the English as a second language context, such as among trainee teachers in Nigeria, is yet to be fully explained. It has been observed that University students (Adebija 1996; 1991 \& Nzinga, 1983) and teachers in training in Nigerian colleges of education (Abe 1991, Ashashim 1991 \& Olajide 1999) are not efficient readers. As observed by Adeyemi (2011), Olajide (2011 ${ }^{\mathrm{a}}$ ), and Olawuyi, Durosaro, Olasehinde and Yahaya (2011), majority of the students in the country's institutions of higher learning do not possess sufficient critical and creative thinking. This may have partly accounted for the problem of graduate unemployability being experienced by the people (Olajide, 2011 \& 2012). Deficit in cognitive skills among college of education student-teachers is particularly worrisome because, on graduation, they are expected to man the junior secondary schools where they are to help in cognitively sensitizing "the leaders of tomorrow" (FRN, 2007; Olajide 1998). (The student-teachers would not be able to give what they do not have!)

Thus, this study was designed to identify, describe and evaluate the cognitive dimensions in the reading comprehension performance of a group of advance student-teachers in a Nigerian college of education. By this, it was hoped that improved teacher preparation and higher literacy enhanced with appropriate critical and creative thinking skills could result.

\section{Research Questions}

Specifically, the following research questions were asked by the researcher:

1. Do cognitive skills manifest in advance student-teachers' reading comprehension performance?

2. Which cognitive skills do student-teachers possess sufficiently?

3. Do the cognitive contents of student-teachers' reading comprehension performance differ along reflect trainees' gender, subject specialization and the structure of the text they confront?

\section{Research Hypotheses}

The hypotheses below were also set for the study:

Ho1: Student-teachers' reading performance contains cognitive skills that do not differ significantly along the divides of gender, subject specialization and text structure.

Ho2: The cognitive skills in the reading performance of student-teachers do not differ significantly on the bases of gender, subject specialization and text- structure. 


\section{Methodology}

The sample for the study comprised 600 hundred student-teachers selected through stratified random sampling from 10 colleges of education, also randomly selected nationally, having zoned Nigeria into 3, east, north and west. Gender was adequately represented by randomly selecting equal numbers of male and female students from each of the academic disciplines (subject specializations) in every sampled college.

The Use of English (General Studies) was the basis of the instrument for the study because the course was common to all the students in every college of Education (NCCE 2009). The instrument comprised a test of reading comprehension. Five texts were employed for the test, to reflect the genres of the five academic schools of the colleges. The schools include Arts, Business and Vocational Education, Languages, Sciences and Social Science. The school of Education was left out for being common to all the students. The questions on each text focused the four cognitive skills of recognizing, deducing, analyzing and synthesizing progressively in that order, to reflect the varying degrees of difficulty entailed by each cognitive skill. All the questions in the test were made compulsory for the subjects. The instrument had been validated using a two-week-interval based test-retest method on an equivalent but excluded sample. The pilot data were then subjected to the Pearson's Product Moment analysis, giving a reliability estimate of 0.76 .

The data obtained from the full study were analyzed using the stepwise multiple regression analysis which was capable of revealing the degrees and direction of interaction among the predictor variables and the various dependent cognitive skills of reading in English. The level of significance chosen for the study was 0.05 .

\section{Results}

Results from the study are presented in the summaries be below.

\section{Table 1:}

Summary of stepwise procedure for scores that tapped the student- teachers' skill of recognizing while reading in English

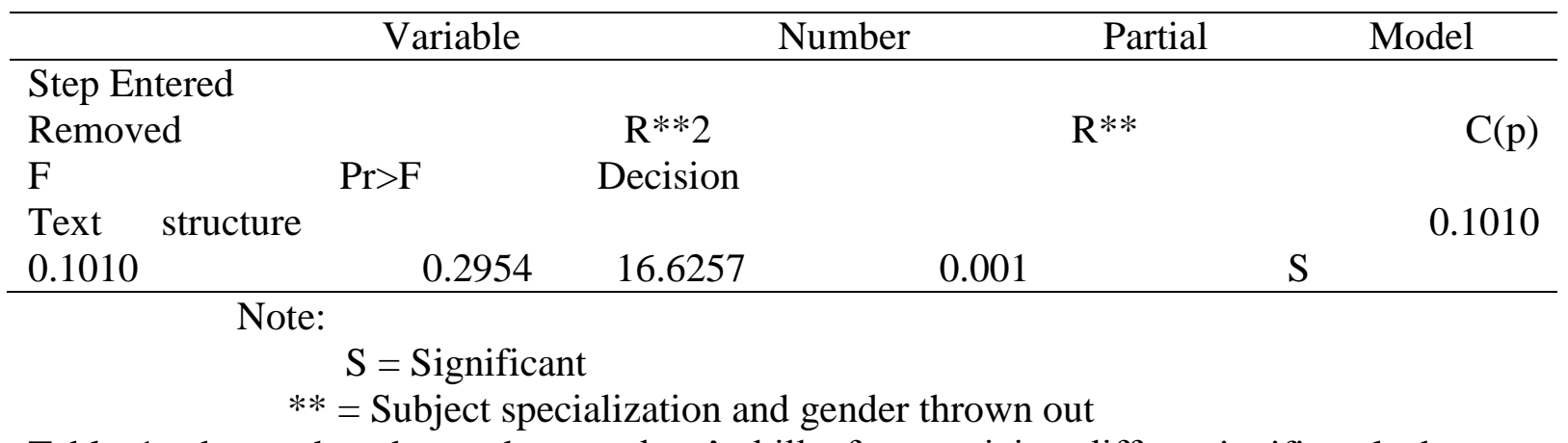

Table 1: shows that the student-teachers' skill of recognizing differs significantly by text structure.

Table 2:

Summary of stepwise procedure for scores that revealed the student- teachers' skill of deducing when reading in English

\begin{tabular}{|c|c|c|c|c|}
\hline Model & \multicolumn{2}{|c|}{ Variable } & Number & Partial \\
\hline Step Entered & & & & \\
\hline Removed & & $\mathrm{R} * * 2$ & $\mathrm{R} * *$ & $C(p)$ \\
\hline $\mathrm{F}$ & $\operatorname{Pr}>\mathrm{F}$ & Decision & & \\
\hline Text structure & & 00.1085 & 0.1085 & 0.1521 \\
\hline
\end{tabular}


Note:

S = Significant

$* *$ Subject specialization and gender thrown out

Table 2 indicates that whereas the cognitive content of the reading performance of student-teachers do not differ significantly along subject specialization and gender, it does on account of text structure.

Table 3:

Summary of stepwise regression on student-teachers' cognitive skill of analyzing while reading texts presented in English

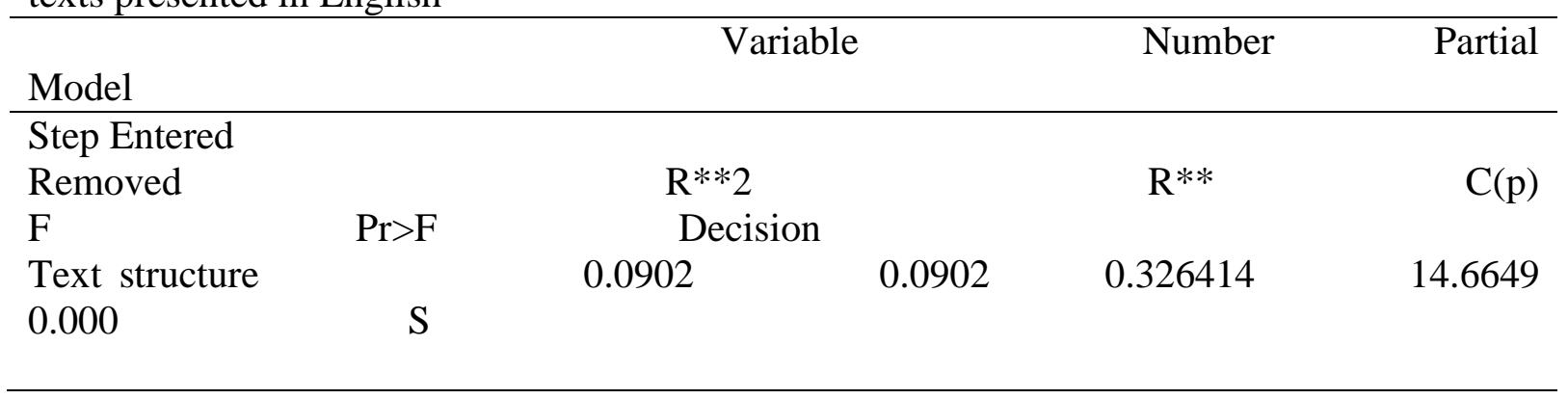

Note:

$$
\begin{aligned}
& \mathrm{S}=\text { Significant } \\
& * *=\text { Subject specialization and gender thrown out }
\end{aligned}
$$

From table 3, it can be inferred that subject specialization and gender do not influence student-teachers' power of analyzing significantly when reading texts written in English in Nigerian Colleges of Education.

Table 4:

Summary of stepwise regression on student-teachers' means in respect of synthesis

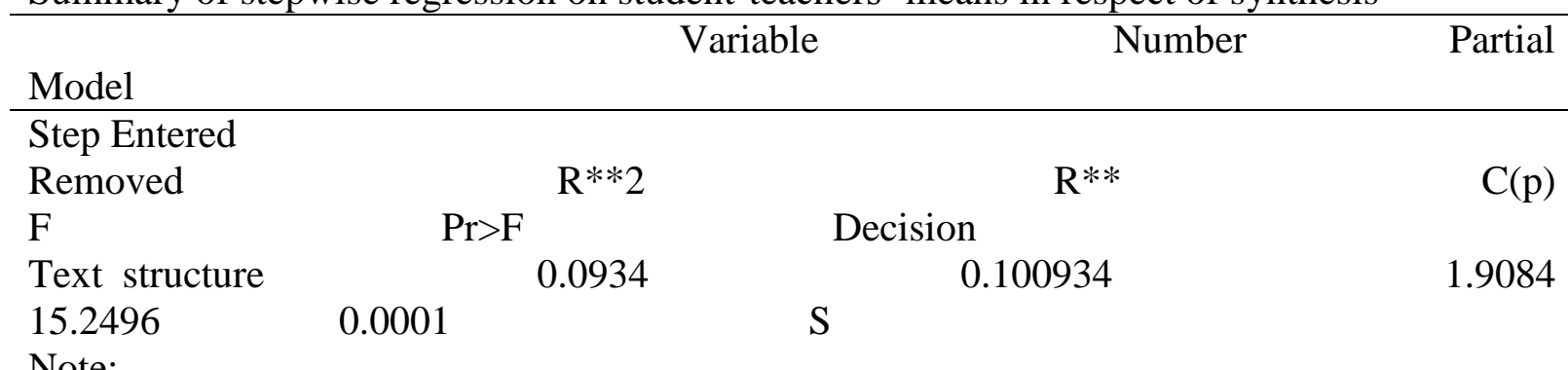

Note:

Note:

$\mathrm{S}=$ Significant

$* *=$ Subject specialization and gender thrown out

The F. value of 15.2496 given on Table 4 indicates that student-teachers' reading related cognitive skill differs based on text structure.

\section{Discussion and Conclusion}

Society attaches great importance to an education that produces rational, creative and constructive learners. Thus, Nigeria needs a crop of younger citizens who should be so cognitively mobilized through education that they can create a greater country. Most of such younger Nigerians can be contacted mainly through the formal school system where the English language remains the main language of teaching-learning. Teachers who have passed 
through the Nigerian colleges of education have much to do with this category of learners, especially those serving at the Upper Basic (former Junior Secondary) level the secondary school. Hence much of the tax-payers money is allocated to the running of the colleges by the government. Following Onyewotu (1991), the present researcher believes that effective cognitive skills are necessary for effective communication.

However, this researcher found that student-teachers in Nigerian Colleges of Education were not efficient at communication. Most of them could not synthesize while reading. Also, gender and subject specialization had no influence on cognitive skills among them, which tends to give credence to the view held by Cronin (2005) that gender has nothing to do with the performance of task.

Further findings from the study appear to support the proposition by, James (1985), Chomsky (1968) and Lenneberg (1953) that no upper schemata (cognitive skills) can manifest in a person's use of language unless s/he has considerably acquired a lower one. Student-teachers did not only vary in their possession of the various cognitive skills of reading in English but also, their cognitive skills and reading comprehension performance decreased as reading tasks increased. Student-teachers were also generally grossly deficient in the higher order skills of thinking, thereby corroborating Abe's (1991) and Nzinga's (1983) submissions that most of Nigerian tertiary students are incapable of effecting creative reading comprehension. This development seems to justify the unanimous call by Olajide (2012; 201I), Adeyemi (2011), and Olawuyi, Durosaro, Olasehinde and Yahaya (2011 ${ }^{\mathrm{b}}$ ) that higher education in Nigeria should increase its thinking related contents.

The implication of it (student-teachers deficiency in thinking) is that teachers, especially of English, in Nigerian colleges of Education may not have emphasized the development of higher order cognitive skills among the students - Olajide (1999) specifically found that most of the examination questions posed by the teachers of language and communication skills in the colleges did not target the higher order cognitive skills.

Also, the finding that most of the finding in the present study that most of the subjects involved could not read to synthesize would tend to suggest that the cognitive processes are open to external influences: student-teachers could not synthesize any texts not related their academic disciplines, which suggests the need for an inter-disciplinary approach in the designing of curriculum for communication skills in English in colleges of Education. Glassman's (2005) paradigm for the development of thinking-based curriculum for all levels of education may be quite relevant, here.

The greatest problem facing student-teachers is probably text structure that significantly influenced all their cognitive skills (Tables 1-4). The structure of the text could enhance or impede cognition as canvassed by Guildford (1970), James (1985), and Piaget (1954). The test items (forming the text) had been deliberately sequenced (structured) into an order of increasing difficulty with a lower skill being subsumed into a higher one. Modern living appears beset with an ever-increasing and ever-present complexity and an adult that cannot appreciably unravel the complexity may not find living easy. It seems ironical, however, that student-teachers whom the society expects to graduate and cause younger Nigerians in the Basic schools to think creatively are themselves unable to undertake very challenging cognitive activities successfully. The need to ascertain that the reading comprehension practices of the secondary school teachers of English appropriately stressed cognitive development among the learners have been suggested by Lawal (1993) and Olajide (1999).

Thus, it can be concluded from this study that the cognitive aspect of reading to learn in English in Nigeria colleges of Education has had worrisome dimensions. Unless drastic measures are taken to sensitize the teachers-teachers cognitively enough, using English across 
courses, many of them would graduate to teach learners who would be of little relevance in the real effort to move Nigeria forward technologically and scientifically.

\section{Recommendations}

It is therefore recommended that a special cognitive component be introduced into the curriculum of Nigeria colleges of Education. The component should be implemented faithfully and imaginatively by reading specialists, applied psychologists and initiated other teachers. Classroom activities, including teacher questions, must be geared towards enhancing, reading-related cognitive skills, not only in English but also in other disciplines. More research is required into other sectors of tertiary education in the country with a view of explaining the cognitive underpinnings of the students' literacy skills, because efficient higher literacy among teachers in any country is desirable for an all-round, integrative national development.

\section{Corresponding Author:}

Dr. Stephen Billy Olajide,

Senior Lecturer in English Education and

Head of the Department of Arts and Social Sciences Education,

Faculty of Education,

University of Ilorin, Ilorin,

Nigeria

\section{References}

Abe, E.A. (1991). Reading problems and their solution at the tertiary level. In Adegbija, E.E. (Eds.), Effective Communication Skills in Teaching and Learning Basic Principles. Ilorin: GNS Division, University of Ilorin 92-101.

Abe, E.A. (1991). Functional reading: A focus on the Junior Secondary School. Literacy and Reading in Nigeria, 5, $80-88$.

Adeyemi, B. S. (2011). Developing critical thinking in students:A responsibility of higher education in Nigeria. In Durosaro, D. O. \& Adegoke, A. A. (Eds.), Higher Education and Globalization: A Publication of the Conference of Faculties of Education in West Africa CEFWA (pp. 71- 78). Ibadan: Stirling-Horden. ISBN 978-032-314-7.

Ashashim, C. (1991). The text structure awareness and reading performance. Literacy and Reading in Nigeria, 5, 155-162.

Chomsky, N. (1968). Linguistic contributions to the study of the mind: Future. In Adams, P. (Ed.) (1972), Language in Thinking. Penguin, 323-363.

Cronin, H. (2005, March 12). The vital ststistics: Evolution, not sexism, puts ua at a disadvantage in sciences. The Guardian, Saturday, $12^{\text {th }}$ March 2005. Retrieved August 2012 from htpp://www.guardian.co.uk/word/2005/mar/12/gender.comment. Eccles, J., Wilgfield, A., Harold, R., \& Blumfield, P. (1993), Age and gender differences in children's self and task perception during elementary school. Child Development, 64, $840-$ 847.

Eckert, P. \& McConnel-Ginnet, S. (2003). Language and gender. Cambridge University Press. Federal Republic of Nigeria (1981), National Policy on Education. Lagos: NERDC Press.

Glassman, M. (2002). Back to Literacy theories. http://www/mun.caleduc./vital/theories/integ ratedcurriculum.html

Guildford, M.G. (1970). Frontiers in thinking that teachers should know about. Reading Teacher, 13,707-713. 
James, S.S. (1985).Cognitive demand of question paper in jamb: implications for teaching and learning English in Nigeria. Journal of English Studies. Ondo: J.A. Ifeduwa (Nig.) Ltd.

Lawal, R.A. (1993). Influence of selected teacher variables on the cognitive levels of classroom reading comprehension questions. Literacy and Reading in English, 6, 83-94.

Lenneberg, E. (1953). Cognition in ethno linguistics. In Adams, P.(ed.)

(1972) Language in thinking. Penguin, 157-169.

May, F. B. (1986). Reading as communication: an interactive approach (second edition).

Columbus: Merrill Publishing company.

National Commission for colleges of Education (NCCE) (1991). Guidelines

on minimum standards.

Nzinga, D.D. (1983). Aspects of reading problems and their implications

for academic achievement among new entrants at University of Ilorin. Literacy

and reading in Nigeria. 1,379-398.

Olajide, S.B. (1991). Patterns of Students performance in the Use of English at the

University of Ilorin. Unpublished M.Ed. Dissertation, University of Ilorin.

Olajide, S.B.(1996). Reading-related skills of thinking in English among students of Nigeria colleges of Education. Unpublished Ph.D. Thesis, University of Ilorin, Nigeria.

Olajide, S. B. (1997). Influence of University students'attitude and field of specialization on their comprehension performance in English. Literacy and Reading inNigeria, 7, 411-424.

Olajide, S.B. (1998). The role of the language curriculum in teacher education: A focus on the NCE General English, Journal of English Studies, vii, 58-67.

Olajide, S.B. (1999) Cognitive level of reading comprehension questions: A study of college of education examination. Centerpoint: A journal of intellectual, Scientific and Cultural Intersest. 9, 1, 55-61.

Olajide, S. B. (2010). Linking reading and writing in the ESL classroom for national reconstruction. International Education Studies (A Publication of the Canadian Center of Science and Education Studies), 3 (3). 195 - 200. ISSN: 1913-9020. Online:

http://www.ccsenet.org/ies. E-SSN: 1913-1939.

Olajide, S. B. $\left(2011^{\mathrm{a}}\right)$. Enhancing critcical thinking in higher education through effective reading instruction. In Durosaro, D. O. \& Adegoke, A. A. (Eds.), Higher Education and Globalization: A Publication of the Conference of Faculties of Education in West Africa CEFWA (pp. 79 - 90). Ibadan: Stirling-Horden. ISBN 978-032-314-7.

Olajide, S. B. $\left(2011^{\mathrm{b}}\right)$. Harmonization of Curricula and Qualifications in Higher Education in Africa: Challenges and Prospects. Paper Delivered at the African University Day

Organized by the University of Ilorin, Ilorin, Nigeria for the Association of African Universities (AAU) and Held in the Auditorium of the University on Thursday, $17^{\text {th }}$ November, 2011

Olawuyi, B. O., Olasehinde-Williams, W. O., Durosaro, I. A. \& Yahaya, L. A. (2011). Critical thinking and higher education in Nigeria. In Durosaro, D. O. \& Adegoke, A. A. (Eds.), Higher Education and Globalization: A Publication of the Conference of Faculties of Education in West Africa - CEFWA (pp. 105-113). Ibadan: Stirling-Horden. ISBN 978-032-314-7.

Piaget, J. (1954). Language and thought from genetic point of view: in Adams P. (ed.) (1972) Language in Thinking. Penguin, 170-179.

Rumelhart, D.E. (1981). Schemata: the building blocks of cognition, comprehension and teaching. Newark, Delaware: International Reading Association. 
Spache, G.D. \& Spache E. S. (1973). Reading in elementary school. Boston Inc., 218-241; 542-572.

Smith, E.B., Goodman; K.S., Meredith, R. (1976). Language and Thinking in school. USA: Holt, Rehinehart and Winston, 81-172.

Thorndike, R.L. (1917). Reading as reasoning: a study of mistakes in paragraph reading. In Melink, J. and Merritt, J. (eds.) Reading Today and Tommorrow. UPU.

Unoh, S.L., (1917). Reading for intellectual development: a psycholinguistic view. Literacy and Reading in Nigeria, 5, 11-21.

Whorf, B. (1941). The relation of habitual thought and behavior to language. In Spier, L. (ed.), Language, Culture, and Personality: Essays in memory of Edward Sapir. Uttah: University Press. 